\title{
Designing a Cooker to Utilise the Natural Waste Rice Husk as a Cooking Gas
}

\author{
Fernando PR*, Karthika U, Parthipan K, Shandarabavan T, Ismail R and Jeeva A
}

Eastern University, Chenkalady, Vanthrumoolai, Sri Lanka

\begin{abstract}
Environmental pollution is big issue in the world, which is from the natural by-products. Some of these byproducts can be transformed into alternative energy source. Rice husk is the one of the natural by-product which is freely available in Sri Lanka that can be used to produce gas for cooking. To utilise the natural by-products a cooker was designed and the performance of the cooker was evaluated. The cooker consists a gasifier, char chamber, air blowing system and a burner. The rice husk was feed into the gasifier through the top of the cooker and lighted. The gas was produced through air force blown into the reactor through the fan to the husk and the atmospheric air from the secondary holes around the burner for proper oxygenation. The performance test was done by boiling 1 litres of water within 7 minutes and the result revealed that the efficiency of the cooker is $27.17 \%$. The efficiency of the cooker could be increased by continuous flow of rice husk feeding. The end product rice husk ash could be utilising as a raw material in cement, bricks and fertilizer production.
\end{abstract}

Keywords: Rice husk gas cooker; Gasifier; Char chamber; Rice husk ash; By-products; Oxygenation

\section{Introduction}

Energy crisis and continuous cost increase in domestic cooking fuels, the society changes their trends to use renewable natural resources such as solar energy, wind energy and biomass materials [1]. Rice husk is the by-product of the rice, which is the natural abundant waste, can be seen in many parts in the country. They are disposed by burning in the field or roads and/or dumping along river or lagoon banks. Averagely, more than 6.5 million metric tons of husks are disposed annually that can be used to produce enough potential energy for domestic usage [2-4]. The husk can produce heat energy about $3000 \mathrm{kcal}$ per kilogram. The energy can be produced in two ways: by direct burning or combustion and by indirect combustion with small amount of oxygen, called biomass gasification and the gas produced during this process is known as synthetic gas [5]. Direct burning increases greenhouse gases and produced global warming effects whereas indirect burning is the thermo-chemical process which changes biomass into useful and environmental friendly energy. Also the cost to produce synthetic gas is much lower than the cost of energy production for the other fuel sources [6]. Therefore, in future biomass gasification technology will be the economical technology use to harvest domestic cooking fuels [6]. Different technologies were carried out to produce synthetic gas. In this work, new cooker was designed, constructed and the performance of the cooker was evaluated.

\section{Methodology}

The cooker was developed base on the industrial application model produced by Belonio et al. [7], which was well designed to meet the specification low cost materials and to avoid the failure of the new product. Flow Chart 1 briefly illustrates the designing, testing and evaluation process.

\section{Designing of the cooker}

Figure 1 shows the rice husk gas cooker, which consists Fan system for air blow, Control switch, Gasifier reactor, Pot support, Burner, Safety shield and Char chamber.

The Gasifier Reactor Figure 2 is the main body of the cooker where the rice husk fill and burn with the limited air flow. The reactor was designed as a cylinder of inner diameter $0.2 \mathrm{~m}$, outer diameter 0.23 $\mathrm{m}$ and height $0.6 \mathrm{~m}$ were made by $\mathrm{Zn}$ coated iron sheets. This was provided with an annular space of was filled with the mixture of cement and rice husk ash of ratio $1: 1$, that serve as an insulator to prevent the heat loss from the reactor. Aluminium net was incorporated to the reactor as shown in the Figure 1 for safety purpose.

The Char Chamber is act as storage for the end product of the rice husk such as ash and charcoal is shown in Figure 3. It is located beneath the reactor and separated by a door that could be open to for easy disposal of the rich husk ash and charcoal. The door is kept close during the operation of the gasifier

Figure 4 shows the Fan used to produce necessary air flow during gasification which directly push the air into the column of the rice husks in the reactor. For this purpose a computer cooling fan is use and can be operate in AC $(220 \mathrm{~V}-16 \mathrm{~W})$ or DC $(12 \mathrm{~V}-3 \mathrm{~W})$ source or by solar system.

Commonly use LPG-Type burner can be utilised for the cooker. However, there is a need to retrofit the burner design to allow proper combustion of gas. Retrofitting includes enlarging of the inlet pipe of the burner and the provisions of a cone to induce secondary air, thereby making the gas properly ignited and burned. The burner consists of holes of diameter 3 to $4 \mathrm{~mm}$ and spaced each other of about $5 \mathrm{~mm}$ is shown in Figure 5.

\section{Working principle of the cooker}

The rice husk was fed into the reactor through the top of the burner reactor while the stopper locked to prevent the rice husk falling into the char chamber. Then the rice husk was lighted with the aid of paper.

*Corresponding authors: Dr. Fernando PR, Eastern University, Chenkalady, Vanthrumoolai, Sri Lanka, Tel: +94718497074/+94652228813; E-mail: Piusrf@gmail.com

Received September 28, 2016; Accepted December 09, 2016; Published January 02, 2017

Citation: Fernando PR, Karthika U, Parthipan K, Shandarabavan T, Ismail R, et al. (2017) Designing a Cooker to Utilise the Natural Waste Rice Husk as a Cooking Gas. Adv Recycling Waste Manag 2: 117. DOI: 10.4172/2475-7675.1000117

Copyright: () 2017 Fernando PR, et al. This is an open-access article distributed under the terms of the Creative Commons Attribution License, which permits unrestricted use, distribution, and reproduction in any medium, provided the original author and source are credited. 
Citation: Fernando PR, Karthika U, Parthipan K, Shandarabavan T, Ismail R, et al. (2017) Designing a Cooker to Utilise the Natural Waste Rice Husk as a Cooking Gas. Adv Recycling Waste Manag 2: 117.DOI: 10.4172/2475-7675.1000117

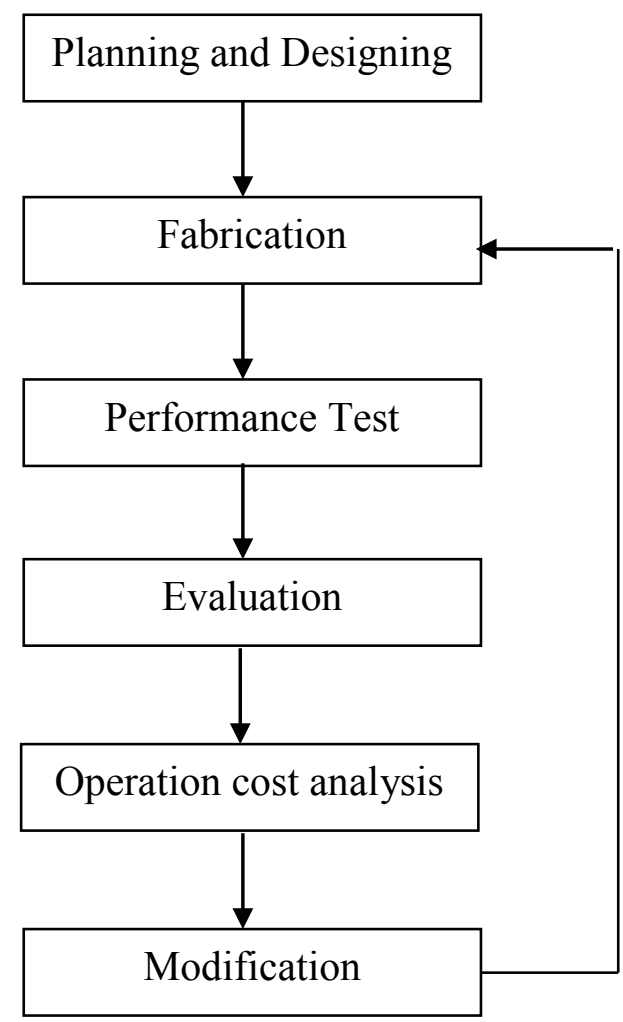

Flow Chart 1: Briefly illustrates the designing, testing and evaluation process.

The burner was placed on top of the reactor, and the fan switched on to blow the air into the chamber. The air blow by the fan and the atmospheric air that enters into the reactor through the secondary holes helps burn the husk.

The rice husk gas stove follows the principle of producing combustible gases, primarily carbon monoxide, from rice husk fuel by burning it with limited amount of air. The rice husks are burned just enough to convert the fuel into char and allow the oxygen in the air and other generated gases during the process to react with the carbon in the char at a higher temperature to produce combustible carbon monoxide (CO), hydrogen $\left(\mathrm{H}_{2}\right)$, and methane $\left(\mathrm{CH}_{4}\right)$ [8-11]. Other gases, like carbon dioxide $\left(\mathrm{CO}_{2}\right)$ and water vapour $\left(\mathrm{H}_{2} \mathrm{O}\right)$ which are not combustible, are also produced during gasification [8-11]. By controlling the air supply with a small fan, the amount of air necessary to gasify rice husks is achieved.

The rice husk fuel is burned inside the reactor in a batch mode. The fuel is ignited from the top of the reactor by introducing burning pieces of paper. The burning layer of rice husks, or the combustion zone, moves down the reactor at a rate of 1.0 to $2.0 \mathrm{~cm} \cdot \mathrm{min}^{-1}$, depending on the amount of air supplied by the fan. The more air is introduced to the rice husks, the faster is the downward movement of the burning fuel. As the combustion zone moves downward, burned rice husks are left inside the reactor in the form of char or carbon.

This carbon reacts with the air that is supplied by the fan and other converted gases thus producing combustible gases. The combustible gases that are coming out of the reactor are directed to the burner holes. Air is naturally injected to the combustible gas, through the secondary holes, for proper ignition thereby producing a luminous blue colour flame

\section{Testing the efficiency of the cooker}

$$
\begin{aligned}
& \text { Fuel consumption rate }(\mathrm{FCR})=\frac{\mathrm{W}_{\mathrm{RHF}}(\mathrm{kg})}{\mathrm{t}(\mathrm{h})} \\
= & \frac{0.9}{\frac{28.5}{60}} \mathrm{~kg} \cdot \mathrm{h}^{-1}=1.89 \mathrm{~kg} \cdot \mathrm{h}^{-1}
\end{aligned}
$$

Specific gasification rate $(\mathrm{SGR})=\frac{\mathrm{W}_{\mathrm{RHF}}(\mathrm{kg})}{\mathrm{R}_{\mathrm{A}}\left(\mathrm{m}^{2}\right) \times \mathrm{t}(\mathrm{h})}=\frac{0.9}{\frac{22 \times 0.2 \times 0.2 \times 28.5}{60 \times 7}} \mathrm{~kg} \cdot \mathrm{h}^{-1} \cdot \mathrm{m}^{-2}=15.072 \mathrm{~kg} \cdot \mathrm{h}^{-1} \cdot \mathrm{m}^{-2}$

Where $\mathrm{W}_{\mathrm{RHF}}$ - the weight of the rice husk fuel used, $t$ - the operating time, $\mathrm{R}_{\mathrm{A}}$ - the reactor area Charcoal production ratio $(\%$ Char $)=\frac{\mathrm{W}_{\mathrm{C}}(\mathrm{kg}) \times 100 \%}{\mathrm{~W}_{\mathrm{RHF}}(\mathrm{kg})}=\frac{141.3 \times 100 \%}{0.9 \times 1000}=15.7 \%$

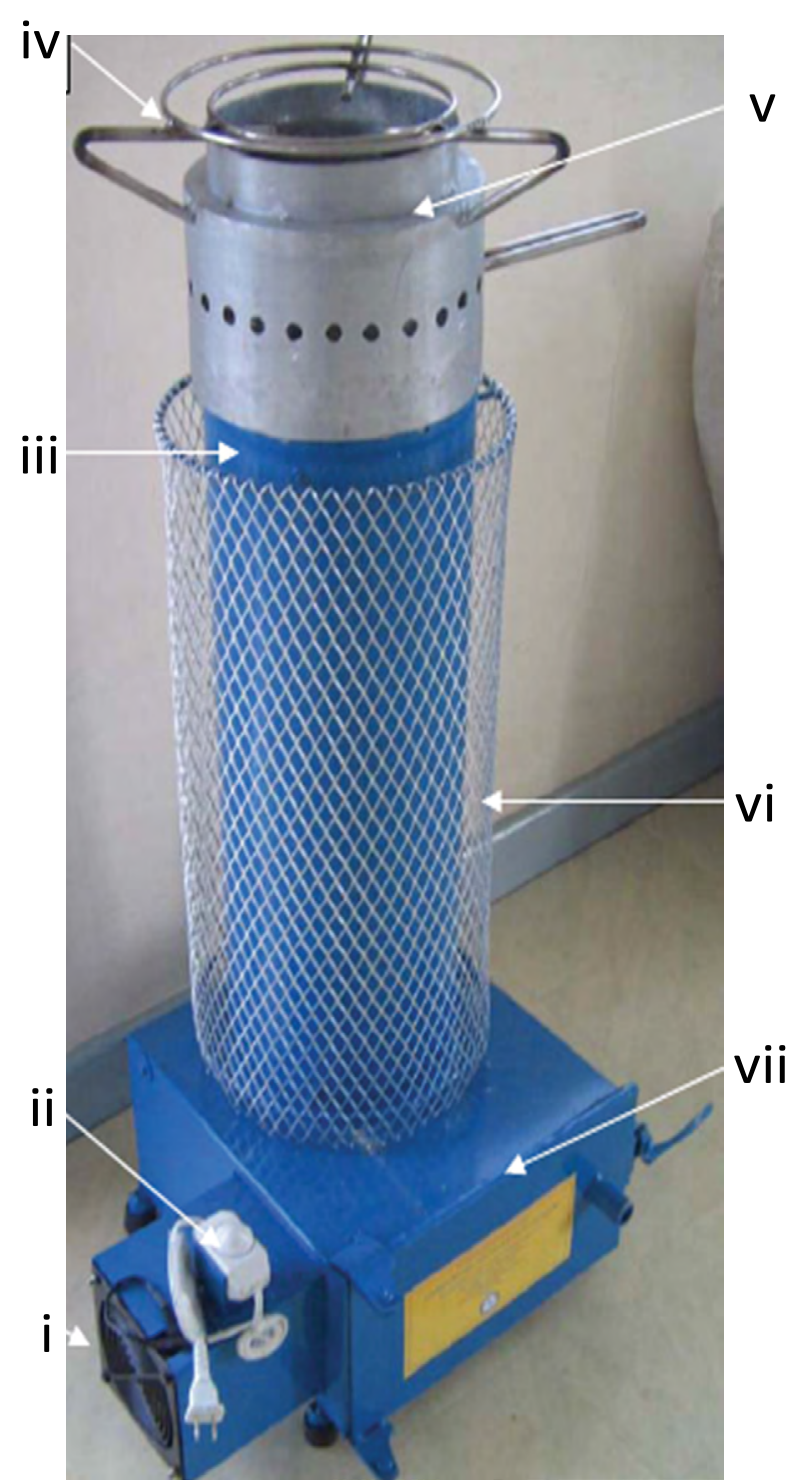

Figure 1: The rice husk gas cooker consists a (i) Fan system for air blow, (ii) Control switch, (iii) Gasifier reactor, (iv) Pot support, (v) Burner, (vi) Safety shield and (vii) Char chamber. 
Citation: Fernando PR, Karthika U, Parthipan K, Shandarabavan T, Ismail R, et al. (2017) Designing a Cooker to Utilise the Natural Waste Rice Husk as a Cooking Gas. Adv Recycling Waste Manag 2: 117.DOI: 10.4172/2475-7675.1000117

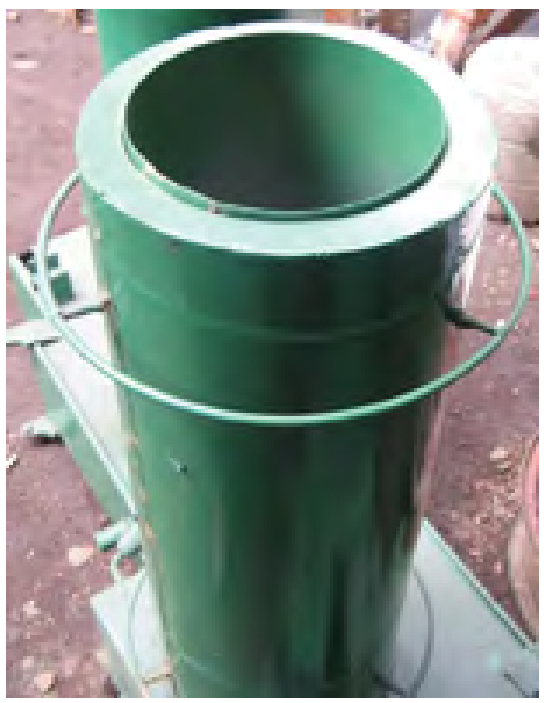

Figure 2: The gasifier reactor of inner diameter $20 \mathrm{~cm}$, outer diameter 23 $\mathrm{cm}$ and height $0.6 \mathrm{~m}$ were made by $\mathrm{Zn}$ coated iron sheets. Use to store the rice husk

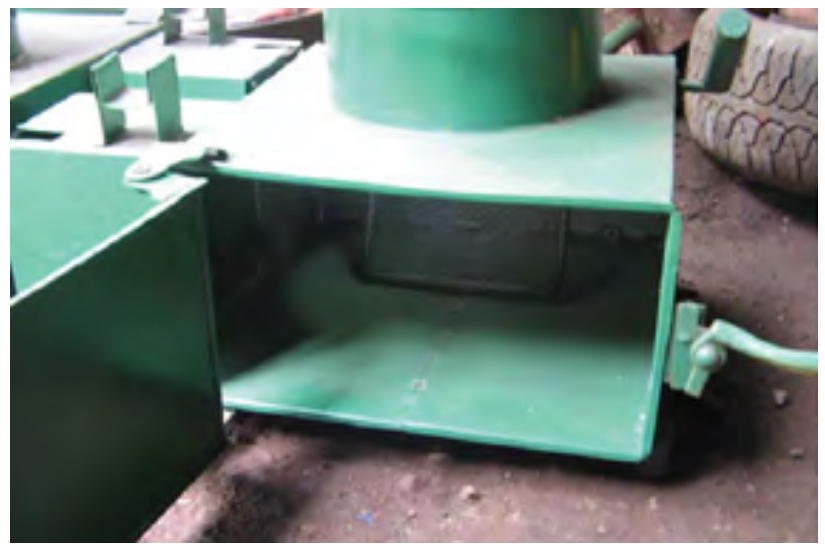

Figure 3: The char chamber of length: width: height is $50 \times 50 \times 20 \mathrm{~cm}$. Which is the storage device of the end product.

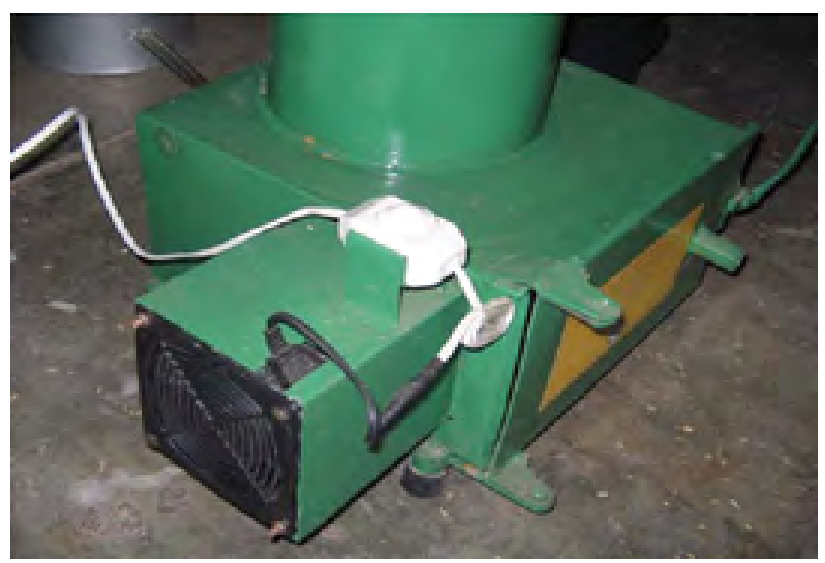

Figure 4: The air blowing system consist a control switch and DC (12 V-3 W) computer cooling fan to blow the air into the glasifier.

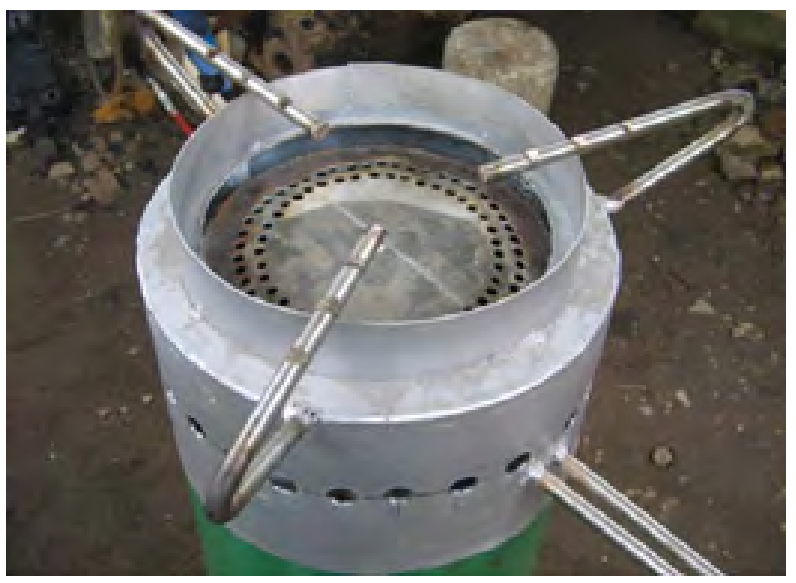

Figure 5: The Gas Burner consists a pot support and a burner with holes of diameter 3-4 $\mathrm{mm}$.

Required heat energy to raise the temperature of the $1 \mathrm{~kg}$ water

$\mathrm{Q}_{\mathrm{H}}=\mathrm{M}_{\mathrm{W}} \mathrm{C}_{\mathrm{W}} \Delta \mathrm{T}$

Where $\mathrm{W}_{\mathrm{C}^{-}}$the weight of the char, $\mathrm{M}_{\mathrm{W}}$ - the mass of the water, $\mathrm{C}_{\mathrm{W}}{ }^{-}$ the heat capacity of the water and $\Delta \mathrm{T}$ - the temperature difference

$\mathrm{Q}_{\mathrm{H}}=1 \times 4200 \times(100-26) \mathrm{J}$

$=310800 \mathrm{~J}$

Required heat energy to evaporate the water

$\mathrm{Q}_{\mathrm{EV}}=\mathrm{M}_{\mathrm{W}} \mathrm{L}_{\mathrm{H}}$

Where $M_{W}$ mass of the water and $L_{H}$ is the latent heat of the water

$\mathrm{Q}_{\mathrm{EV}}=1 \times 23 \times 10^{6}=23 \times 10^{6} \mathrm{~J}$

Thermal efficiency $(\%)=\frac{\left(\mathrm{Q}_{\mathrm{H}}+\mathrm{Q}_{\mathrm{EV}}\right)}{\mathrm{W}_{\mathrm{RHF}}(\mathrm{kg}) \times \mathrm{H}_{\mathrm{F}}\left(\frac{\mathrm{kcal}}{\mathrm{kg}}\right)} \times 100 \%=\frac{(310800+23000000)}{0.9 \times 465}=27.17 \%$
Results and Discussion

Testing and evaluation of its performance revealed that the stove requires $0.9 \mathrm{~kg}$ of rice husk as fuel in one full load. The fuel consumption of the stove is at an average rate of $1 \mathrm{~kg}$ of rice husks per hour (Tables 1-4). Combustible gas is produced within 5 to 10 minutes from ignition of fuel. One and a half litres of water can be boiled in the stove within 14 to 20 minutes, depending on the size of the opening of the gas valve at the burner. The average gas temperature coming out from the reactor is $185^{\circ} \mathrm{C}$. The temperature at the bottom of the pot averaged at $420^{\circ} \mathrm{C}$. Based on the overall thermal efficiency the computed power output of the stove is $2,028 \mathrm{kcal} . \mathrm{h}^{-1}$ or $1,014 \mathrm{kcal}^{-1} \mathrm{~h}^{-1}$ burner. Moreover, the specific gasification rates of rice husks are approximately $130 \mathrm{~kg} . \mathrm{h}$ ${ }^{1} \cdot \mathrm{m}^{-2}$. The fire zone moves from the bottom to the top of the reactor at a rate of $2.2 \mathrm{~cm} \cdot \mathrm{min}^{-1}$. The computed thermal efficienc of the stove is $26 \%$ and the percentage char produced is $32 \%$ of rice husks consumed. There is a need to push the char out of the char box from time to time to replace burned rice husks with new ones. Initially, operation is quite difficult But, the longer the stove is operated and its operation is mastered, the more it becomes convenient to use and the more its benefits are enjoyed. Some of the advantage features of the stove are: (1) Uses rice husks as fuel; (2) Produces combustible gases for cooking; (3) Continues operation until all cooking preparations are finished 
Citation: Fernando PR, Karthika U, Parthipan K, Shandarabavan T, Ismail R, et al. (2017) Designing a Cooker to Utilise the Natural Waste Rice Husk as a Cooking Gas. Adv Recycling Waste Manag 2: 117.DOI: 10.4172/2475-7675.1000117

Page 4 of 4

\begin{tabular}{|c|c|c|c|}
\hline No. of Testing & $\begin{array}{c}\text { Weight of the fuel } \\
\text { (Full load) (kg) }\end{array}$ & $\begin{array}{c}\text { Fuel start up time } \\
\text { (min) }\end{array}$ & $\begin{array}{c}\text { Gas ignition time } \\
\text { (s) }\end{array}$ \\
\hline Test 1 & 0.9 & 3.0 & 62.3 \\
\hline Test 2 & 0.9 & 3.0 & 61.4 \\
\hline Test 3 & 0.9 & 2.3 & 75.0 \\
\hline Average & 0.9 & 2.8 & 27.4 \\
\hline
\end{tabular}

Table 1: Efficiency test result of the cooker.

\begin{tabular}{|c|c|c|c|}
\hline $\begin{array}{l}\text { Volume of water } \\
\text { (1 liter) }\end{array}$ & $\begin{array}{l}\text { Initial temperature } \\
\left({ }^{\circ} \mathrm{C}\right)\end{array}$ & $\begin{array}{l}\text { Final temperature } \\
\left({ }^{\circ} \mathrm{C}\right)\end{array}$ & $\begin{array}{l}\text { Time taken to boil the water } \\
\text { (min) }\end{array}$ \\
\hline Test 1 & 26 & 100 & 6.9 \\
\hline Test 2 & 26 & 100 & 6.5 \\
\hline Test 3 & 26 & 100 & 6.5 \\
\hline Average & 26 & 100 & 6.7 \\
\hline
\end{tabular}

Table 2: Efficiency test result of boiling the water.

\begin{tabular}{|c|c|c|}
\hline Cooked types & Cooked items & Time taken to cook (min) \\
\hline Boiling & Water & $6.5-7$ \\
\hline Frying & Egg & $2.5-3.0$ \\
\hline Boiling & 1 piece of fish curry & $17-18$ \\
\hline Cooking & Rice+water (3 cup each) & $10-12$ \\
\hline
\end{tabular}

Table 3: Efficiency test result for various foods.

\begin{tabular}{|c|c|c|c|}
\hline Description & Rice husk cooker & Kerosene cooker \\
\hline Investment & 3000.00 & 1500.00 \\
\hline Fuel & - & 100.00 (per day) \\
\hline Total cost & - & 100.00 (per day) \\
\hline
\end{tabular}

Table 4: The cost analysis.

(4) Fast ignition of fuel and almost no smoke during operation; (5) Operates on AC line or on DC using a battery; (6) Low $\mathrm{CO}_{2}$ and black carbon emissions; (7) Simple design and fabrication making the technology affordable; (8) Safe to operate; and (9) Burned rice husks can be used as soil conditioner.

\section{References}

1. Mirani AA, Ahmad M, Kalwar SA, Ahmad T (2013) A Rice Husk Gasifier For Paddy Drying. Sci Tech and Dev 32: 120-125.

2. Asanka SR, Shantha $P$ (2011) Electricity generation using rice husk in Sri Lanka: Potential and viability. National Energy Symposium, pp: 104-108.

3. Beagle EC (1978) Rice Husk Conversion to Energy. FAO, Rome, pp: 139-154.

4. Anderson PS, Wendelbo P, Reed TB, Belonio AT (2008) Super-clean combustion of solid biomass fuels in affordable TLUD cookstove. Beyond Firewood: Exploring alternative fuels and energy technologies.
5. Khan AA, Rafiq-ur-Rehman R, Farooq MA (1998) Agricultural Mechanization in Asia, Africa and Latin America. FAO 29: 21-28.

6. Pathak BS, Singh A (1988) Husk utilized as fuel. Journal Agricultura Mechanization in Asia, Africa and Latin America 19: 65-70.

7. Belonio A, Emmanuel S (2011) Francisco CA Two -Burner continuous type rice husk gas stove developed for household/small cottage industry.

8. Rajvansh AK (2013) Nimbkar Agricultural Research Institute. Phaltan-415523.

9. Njogu P, Kinyua R, Muthoni P, Nemoto Y (2015) Thermal Gasification of Rice Husks from Rice Growing Areas in Mwea, Embu County, Kenya. Smart Grid and Renewable Energy 6: 113-119.

10. Bhattacharya SC, Abdul Salam P (2002) Low greenhouse gas biomass options for cooking in the developing countries. Biomass and Bioenergy 22: 305-317.

11. Suvarnakuta P, Suwannakuta $P$ (2006) Biomass Cooking Stove for Sustainable Energy and Environment. The $2^{\text {nd }}$ Joint International Conference on "Sustainable Energy and Environment" (SEE 2006). 